\title{
Social Justice and Financial Capitalism: Some Notions on Risks, Hierarchies, and Value
}

\section{by Teppo Eskelinen}

\section{Abstract}

The recurring financial crises and intensive financialisation force a reconsideration of theories of justice. This article analyses financial capitalism as an ideal-type. In ideal-typical financial capitalism, risks and positions of vulnerability take a pronounced role in the determination of social positions. Risks also come in a specific ontological form. Further, the analysis extends to the production of value in financial capitalism and its relation to a particular logic of determining social positions. The article discusses, how should theories of justice be updated to accommodate this particular ontology of risks. This requires also making a distinction between explicit and implicit priority orders in a society.

In this article, I analyse financial capitalism from the viewpoint of the theory of social justice, focusing specifically on the allocation of risks as determinants of social positions. While financial capitalism is extensively theorised in sociology and political economy (Calhoun \& Derluigian 2011; Varoufakis 2013; Nesvetailova 2007; Marazzi 2011; Palley 2013; McMurtry 2013), it lacks clear definitions and remains undertheorised in theory of justice. This is somewhat surprising given the deep sense of injustice associated with recent outcomes of intensive financialisation. ${ }^{1}$ My aim is not to formulate a comprehensive alternative theory, but to show the need for theoretical reconsideration and sketch some starting points for a more plausible theory.

I will present financial capitalism as a specific political form with distinctive economic dynamics and a distinctive logic of producing social hierarchies. Pointing out the key characteristics of this political form enables comparisons between financial capitalism and productive capitalism. I will argue that the ascent of financial capitalism has both partially changed the 'currency' of social justice and created new kinds of unjustifiable hierarchies. 
In order to be relevant in the context of financial capitalism, a theory of social justice needs to be updated so that it takes into account the current changes in the value creation patterns and priorities in the economy. Particularly, a specific logic of production and reallocation of risks emerges as the key feature of the social order of financial capitalism. These risks are not only reallocated social risks, but rather risk generation and management becomes a key economic dynamic and arena of political struggle. Further, the meaning of 'risk' in financial capitalism is also ontologically different from its meaning in productive capitalism. Traditional theories of justice lack the vocabulary to adequately theorise this feature of financial capitalism.

The article proceeds as follows. I will begin with formulating an account of the meaning of financial capitalism, and how financial capitalism can be analysed as an ideal-type. In section two, I will make more detailed descriptions of what financial capitalism means in value-production and how it changes the priorities of main economic agents. This entails a criticism of seeing financial capitalism merely as an outcome of deregulation. Subsequently, I will analyse the political form of financial capitalism, with a specific emphasis on the role of risks in the economy. Further, in sections four and five, I turn to the challenges for theory of justice. I discuss the difference between the explicit and implicit priority orders, and how the existing theories of justice focus exclusively on the distribution of money, or conceptualise risk in a way which is ontologically different from the meaning of risk in financial capitalism. Finally, in section six, I will draw some philosophical and political conclusions.

\section{Definitions: theory of justice and financial capitalism}

The realisation of social justice requires that goods/burdens are distributed according to plausible normative principles. Yet the precondition of this is to locate the goods/burdens relevant for normative consideration within the given social setting. Goods or burdens are relevant in a social setting if they are key to determining social hierarchies and possibilities for individual wellbeing, and cannot be reduced to some other good or burden (such as money). For example, status positions were clearly more important in ancient times, and the idea of reward on the basis of diligence was a revolutionary idea at a quite late point of time (Fleischacker 2005). With the birth of capitalism, money became the overwhelmingly most important medium in determining of social positions, to the point that sometimes it is difficult to see any other 'currency of justice' ${ }^{2}$ even existing. Yet this does not mean that new social forms could not again bring about new goods or burdens relevant for normative consideration. While the basic idea of justice remains intact, 
normative concepts need to be informed by the existing social reality.

In order to analyse social justice in financial capitalism, also a working definition of the essence of financial capitalism is of course needed. The foremost matter is to establish its distinctiveness. Has not capitalism always been 'financial', as financial institutions have been central to its operation for the duration of its existence? I will argue that in comparison to productive capitalism, financial capitalism has a different focus in value creation, and constructs hierarchies partially in a different manner.

Financial capitalism, like all economic systems, materialises with a number of local variations. This allows for two alternatives for the analysis. Either to locate the common characteristics of actual variations, or to construct an ideal-type, emphasising the distinctive characteristics of the system, which do not necessarily equal the common denominators of these variations. Here, I will take the latter approach and present both financial capitalism and productive capitalism as ideal-types. This specific form of abstraction is needed, if a concept like 'financial capitalism' is to be analysed in the sense of what is distinctive about the system.

While typically the ideal-type is 'a methodology suited for making comparisons between the type and empirical reality' (Psathas 2005), it can also facilitate the analysis of the distinctive features of an economic system. Intuitively, the construction of ideal-typical form of production is quite straightforward: it is not difficult to tell apart capitalism and feudalism, for example, while acknowledging the existence of a variety of capitalisms. ${ }^{3}$ Ideal-type methodology also enables recognising features of social forms which are still in the process of formation. For instance, the distinctive features of capitalism (abstract labour, commodity form, etc.) could be analysed long before capitalism become a pervasive economic logic - as was done in early Marxist theory. ${ }^{4}$ Further, this form of analysis does not require the existence of a pure form of the analysed political system. Especially in the case of capitalism, a system without checks and balances and political counter-forces would be unlikely to sustain itself for long. Yet despite the need for such balances in the real world, ideal-types can be constructed to show what is distinctive in the system.

\section{Financial capitalism: an analysis}

Perhaps the most apparent way to analyse financial capitalism would be though an analysis of economic history. Financial capitalism could indeed be easily seen as the dynamic slowly replacing earlier forms of capitalism; it is what began to emerge after the crisis of productive capitalism in the 1980s onwards. The recent decades have seen a substantial growth of the financial sector in relation to the productive sector, ${ }^{5}$ as well as deregulation of the 
former (Orhangazi 2014). Capitalism has generally become more financialised. Financial deregulation and a push for financial competition, new forms of financial innovation and an attack against welfare states all have characterised the economic and political life of this era (Starke 2006; Sherman 2009; Larner 2006).

Further, it is very common, yet not quite as accurate, to describe the ascent of financial capitalism through the idea of relaxation of regulation of finance and the resulting 'wild west' model of finance. According to such idea, the role of finance can be described simply by placing economic systems on a regulation-deregulation -axis. As the financial capitalist era was preceded by a more regulated capitalist system, which was preceded by a less regulated system, it would be easy to see the relations between politics and finance as a kind of a 'regulation pendulum', and the present day as 'return to finance'.

In addition, it might be difficult to think of the present order as anything novel, as even financial crashes have been known to take place already in the 17th century (Dash 1999; Reinhart \& Rogoff 2011). In some sense, present financial capitalism is indeed a political re-enactment of the earlier eras of 'big finance'. Also in economic theory, already J.M. Keynes emphasised the chronical instability of the capitalist system (Vicarelli 1984). Another early theorist, Hyman Minsky, also emphasised the role of 'fictitious liquidity' created by an unstable banking system (Kregel 2014, 132-135).

Yet, financial capitalism cannot be reduced to the notion of less regulation or 'less government'. 'Less government' does not as such dictate a given form of finance and given finance-production relations. The notion of 'deregulation' can itself be misleading, as it suggests the existence of a spontaneous logic (which can be subject to more or less regulation). Yet the recent changes in economic forms can be properly explained only as an interplay between economic and political dynamics. 'Deregulated' financial activity is often created by the very process of regulation, rather than set free by it. Financial regulation often consists of what John Searle famously called 'constitutive rules' (Searle 1969; Cherry 1973). Most 'financial innovations' and the like would thus simply not exist without 'regulation' ${ }^{6}$. Further, some phenomena which were largely absent from earlier forms of deregulated finance, are constitutive of the form and priorities of financial capitalism, most noteworthy of which are financial offshore centres (Palan et al 2009).

What is distinctive about 'financial capitalism', then, is not a particular level of regulation but rather a specific economic logic. This logic manifests especially in the value-creation model of this system. Financial offshore centres are not significant players in the system primarily because they liberate given financial flows from regulation, but because they reorganize priorities and value-creation in the economy. This specific economic logic 
can be best described though the two following main trends.

First, in financial capitalism the nucleus of value-creation changes from producing goods to manipulating and commodifying expectations about the future. In finance, expectations can be turned into financial assets, and financial value in general is created by manipulating and upholding given expectations of the future. This becomes the driving logic of the whole economy. The most profitable (and therefore most incentivised) functions in the economy do not relate to producing anything, but creating and sustaining collective anticipations about the future. A visible aspect of this phenomenon is the general tendency to prioritise stock value over productive profitability, which means that also productive firms have ceased to set their criteria of success on the basis of competitiveness in output, but rather on the basis of expectation of future stock value.

Yet of course, 'financial capitalism' does not mean that production would have ceased to create economic value. The concept rather refers to a system in which finance dictates the priorities in production and the economy more generally (rather than conditions of production determining conditions of finance). Also, productive investment is based on the anticipation of financing conditions in the future (conditions of credit) and the price of financial hedging products, rather than merely prospects of the price of production and market expectations. Future perceptions are then the drivers of the economy, rather than for instance the potential to increase production. Partially, the former is of course a reflection of the latter; yet what is noteworthy is that key determinants in the economy are masspsychological rather than 'real economic' factors.

Because finance is vastly more profitable than production, several productive firms begin to push the boundary between production and finance by launching financial subsidiaries. The functions of non-financial corporations become generally financialised (Orhangazi 2008, Stockhammer 2004). As the famous anecdote tells, before the US 2007 crash, General Motors was making good profits on providing consumer credit for purchasing cars, and the consumer finance arm of the company was essentially offsetting the operation losses of car production. In other words, the financial arm enabled production. ${ }^{7}$ The logical next step would be to cease producing anything.

Second, the firms and the banks undergo an institutional reorganisation and a reorientation of their activities. The political push to increase competition within finance changes not only what banks can do, but also what banks are. In productive capitalism, the role of the banks is close to their textbook function: to act as intermediaries between savings and loans (Rethel \& Sinclair 2012, chapter 2), and to channel funding to profitable productive enterprises. But in financial capitalism, saving becomes ever 
more investment-oriented (in mutual funds, etc.), while the companies' need for bank loans decrease as they can get their funding directly from the capital markets. This leads the banks to seek new functions by increased commodification ('hedging everything') and financial innovation, that is, ostensibly creating more efficient risk management systems but effectively creating and externalising risks.

The global firm, for its part, ceases to be a site of production; rather, after outsourcing everything from production to the maintenance of the head office, the global firm has become mostly a system of co-ordination of income and outflow of money, and optimising risks in relation to hedging costs. Fundamentally, the global firm is a site of managing (containing, commodifying, externalising) different categories of risks related to the coordination of outsourced functions in various geographical locations (LiPuma \& Lee 2004), the complexities of markets, and the different temporalities of finance. The firms also seek protection from 'counterparty risks' or 'political risks' (that is, political changes), and the banks, seeking new functions, have taken the role of providing these new kinds of insurances in the form of derivatives (ibid., 20). In brief, then, the global firms have essentially become 'risk planning centres', the main function of which is to reallocate, contain and manage different forms of risks. This of course means also externalizing risks when possible. Pushing risks on others has indeed become a major economic-political struggle and a key element in construction of social hierarchies.

\section{The political form of financial capitalism}

As the main function of the new global firm is to manage uncertainties, it is eager to engage politically to see that any risks are borne by other parties than the firm itself. Key financial and other commercial agents are then in the business of externalising uncertainties, and, in the case of banking, creating risk structures for profit. As these risks become systemic, they are de facto assumed by governments, as the creation of these risk structures typically leads financial institutions to become 'too connected to fail'. ${ }^{8}$ Thus, financial entities tend to have a specific position in the political order of financial capitalism. The banks can profit from practices, which simultaneously extend systemic risks to the wider society. The system's focus on creating and reallocating risks thus pushes a variety of uncertainties on the salaried population. Vulnerability is, in financial capitalism, a general condition, not a particular risk which could be addressed by social insurance, for instance. For this reason, financial capitalism is sometimes characterised as 'the financial risk society' (Watson 2007; chapter 1). 
Financial capitalism takes future as its object of commodification. The most traded market items are different kinds of synthetic securities, insurances and other contracts, that is, assets which do not imply ownership to anything, but rather stipulate responsibilities and priorities in an event of a materialisation of a market risk. To a large extent, finance gives up its textbook function to channel funds for productive enterprises, rather mostly feeding into itself. As the critical financial economist Jan Toporowski puts it: 'in an era of finance, finance mostly finances finance' (Toporowski 2010, 92).

Some characteristics of the political form of this ideal-typical financial society result from these economic aspects. Financial capitalism prioritises finance. This means securing the smooth functioning of financial markets (at the expense of other functions, if necessary), and bailing out financial institutions when needed. Often this logic of priority has been quasijudicially institutionalised, as governments adopt several kinds of 'rules-based programmes designed specifically to lock-in asset values' (Watson 2007, 19; see also Gill 1998), in order to uphold the structural governance framework of global financial capitalism. Apart from protecting financial asset value from fluctuation and minimising risks related to political changes, the politics of financial capitalism aims at collectively assuming expenses related to uncertainties, which finance would otherwise have to bear. As an unavoidable characteristic of such system, other functions are more vulnerable.

This political system entails several mechanisms for the reallocation of risks. Some of this reallocation takes place by market means (for example, choosing or not choosing to buy an insurance), some by changes in the grounding political structure. For instance, there has been a strong push to shift the organisation of social insurance from public provision to market provision, and it is a question of social justice in its own right, whether this kind of system is desirable. In the political order of financial capitalism, individual responsibility is emphasised through the 'financialisation of everyday life' (Langley 2009; Martin 2002). This means that social security and saving come ever more often in the form of investments and insurance deals.

Further, sometimes reallocation takes places by pushing uncompensated risks on others, such as what banks attempt to do in the process of securitisation (Kothari 2006, 761-762). Banks are keen to use the complexity of some securities to conceal the true risk content of such assets. Yet further, some risks are created intentionally in the course of 'financial innovation'. As discussed above, the financial capitalist system not only reallocates, but generates risks. The magnitude of existing risks is indeed not 
objective or constant, but new financial innovation also creates them. The matter is then not only, to what extent the government mitigates social risks, but that the core of the economy consists of agents whose very function is to create, contain and externalise risks and whose mode of value production depends on the struggle over the hegemonic perceptions of likely futures.

The significance of risk allocation for social justice is of course not limited to financial capitalism. Also, productive capitalism has a distinctive logic of risk distribution. In early capitalism, for instance, workers had little protection over ageing, illness, and such, which left them quite vulnerable. It might seem that what has changed is merely the functioning of measures to mitigate risk, in other words the welfare state with provisions for health, unemployment, and such. In productive capitalism, first, work safety was politicized, and second, welfare state functions were pushed (against what was posed as market rationality), to offset risks specific to the system. Yet financial capitalism changes the ontology and economic status of risk structures. Again, in financial capitalism, risks are not side-effects, but rather a central category in the very process of economic value creation: often, creating economic value is optimising and reallocating risks.

\section{Social justice: explicit and implicit orders}

So how should financial capitalism, in contrast to productive capitalism, be evaluated from the viewpoint of social justice? A useful starting point here is the distinction between explicit and implicit social priority orders. Any social system, small or large, contains both kinds of orders. For an illustrative example of a small-scale system, any workplace has both rules of employment (contracts, explicitly stipulated rights of the employees, etc.), dictating the terms in a business-as-usual scenario, and (implicit) rules stipulating how to manoeuvre in a situation of economic distress. Despite the implicit nature of the latter, these rules can be generally recognised. It is not uncommon, for instance, that everyone in a workplace knows who would have to adjust in an economic downturn (for example, lose one's job first).

This knowledge might not be ever articulated, but is nevertheless an existing hierarchical arrangement. Implicit orders are a form of rules as well, because of both their real impact and their recognised content, thus deviating from real improvising in exceptional situations. Even if this logic does not necessarily ever materialise, it is nevertheless a very real hierarchy of social positions and therefore highly relevant to social justice. As a genuine social hierarchy and logic of allocation of goods/burden, the implicit logic deserves attention in normative theory quite like to explicit logic. 
In several social contexts, making the distinction between these explicit and implicit logics is less necessary. The distinction begins to matter when two conditions are met. First, the explicit and implicit orders are very far apart. In this situation, the rules of the game regarding social positions, priorities in adjusting and bearing the burdens, and distributive logics tend to change completely when the implicit logic is activated. Second, the regular occurrence of the conditions activating the implicit logic seems to be part of the normal operation of the system. In other words, the failure of the explicit logic comes in patterns rather than as real exceptions.

Financial capitalism meets both conditions. Not only does a 'financial crisis' overturn the explicitly articulated promises of economic priorities, social insurance and basic needs, but also these financial crises appear with a remarkable regularity. ${ }^{9}$ Financial capitalism is characterised by systemic instability, caused by general volatility and intentional creation of risk structures, which build 'systemic risks'. Especially speculative activity and cross-securitisation both create quick profits and contribute to such risk generation. Therefore the implicit logic is activated clearly more often than in most social orders. Also, as the post-crisis policies tend to follow a regular pattern, these policies are clearly matters of activation of an implicit logic, rather than improvising. In financial crises, politicians are de facto compelled to prioritise saving the major financial agents with bail-outs, as the alternative in the given situation would be a full halt to the functions of the economy. This logic of prioritisation is built into the system before the occurrence of the crisis. Social security is routinely compromised because of the felt compulsion by the governments to protect financial interests and save key financial institutions. These crises have also shown the high vulnerability of ordinary home-owners and workers, implying that the logic of allocation of burdens is not restricted to the financial market, as financial economics would suggest.

In principle, priority orders in financial capitalism are quite explicit. Risks are commodified uncertainties, meaning that explicit judicial contracts stipulate, how burdens are shared when risks materialise. Very complex structures of risk are created by cross-securitisation. It is sometimes impossible to evaluate the accuracy of risk assessment, but nevertheless financial securities and the related risks and traded on an open market. Theoretically, all decisions to bear risks are free market decisions. Further, the governments still provide some universal social insurance, with explicit rules regarding for example welfare payments in the case of unemployment.

Yet the financial economics and social risk perspectives only describes the functioning of the explicit logic. What is important is to see the implicit logic as a real and existing logic of allocating social positions, not an 
exception to a rule. The implicit logic prevalent in financial capitalism shows that the system is based on systematic production of positions of vulnerability, rather than their production randomly or as a side-effect of production of value.

\section{Theories of justice and the ontology of risk}

Concepts most often employed in theory of justice, such as rights and resources, are not sufficient in describing the form of social injustices typical in financial capitalism. Because of the focus on risks both in value creation and struggle over social positions, merely referring to the distribution of income is misleading. Indeed classical theories of social justice presuppose the conditions of productive capitalism as they quite exclusively theorise the distribution of money. Most notoriously Rawls' difference principle is explicitly a normative guideline for the just distribution of wealth and income (Rawls 1971; §11-13), while Robert Nozick is preoccupied with analysing the right of an individual to his/her property (Nozick 1974, 150182). This means that such normative theories tend to ignore the role of the allocation of vulnerabilities. Further, these theories hardly take into account the importance of negotiation between individuals and corporations; indeed, corporations as political agents are hardly mentioned.

Of course it is possible to use such theories to analyse just risk allocation. Nozick's theory can be seen as attempting to justify any 'network of private agreements' (Nozick 1974, 150-153), while Rawls can be seen as favouring a broader risk-bearing structure. Risks figure in Rawlsian theory, for instance, in theorising the determination of an ideal division of moral labour (Eskelinen \& Mäkinen 2014). Negotiation of positions of risk and protection are seen as matters of grounding justice: any society has to choose some basic institutions, which include some allocation of risk-bearing responsibilities. These institutions can then be assessed from the viewpoint of social justice. Yet if financial capitalism is to be analysed, a broader conception of risk needs to be incorporated into these theories. Also neither Rawls' 'forward-looking' nor Nozick's 'backward-looking' justification of property is sufficient for analysing a system, in which an ever growing body of property consists of contracts, gambling bets and stipulations on riskbearing orders.

Yet some theories of justice make a point in insisting on the importance of the security of individual functioning. The most famous scholar to promote this view is Amartya Sen, who attempts to base his ethical theory on individual functionings rather than resources (Sen 1993). The centrality of functionings implies that the notions of risk and protection 
should be built into measures of social (dis)advantage. Also for example Jonathan Wolff and Avner De-Shalit have argued for the need to conceptualise advantage and disadvantage in terms of how secure a given functioning is (Wolff \& De-Shalit 2007, 68-72). Wolff and DeShalit use the example of an area inhabited by man-eating tigers in India, when discussing the notion of risk: surely people who have to pass a tiger habitat to earn a living are worse off than people with a different commuting path but an equal pay, even though not all of the former ever experience a tiger attack.

Yet a number of key aspects of financial capitalism discussed above are not sufficiently captured by these accounts of risk allocation. First, what is not theorised is the discrepancy between the explicit and the implicit order. The key question is, which people, which institutions and which functions in the society are de facto protected in the event of systemic crisis and who benefits from the production of systemic risks.

Second, the reality of financial capitalism entails something of a unique category of risks. While the theme of risks and vulnerability is indeed recognised in some theories of social justice, the discussions tend to lean on a given social ontology. This ontology presupposes, that risks can be treated as mere externalities and possibilities of having bad luck. Thus risks are either aspects of reality (such as the risk of illness or bad weather), sideproducts or externalities, such as health risks related to pollution, or social risks directly related to production (such as unemployment). All these categories of risks can be properly analysed within the conceptual framework of functionings and risk-bearing structures of basic institutions. Yet in financial capitalism, the production of risks is in the heart of value production, as the central economic activity is reorganising expectation and commodifying future.

The need for a reconceptualisation of risk is explicitly visible in the reliance of the notion of 'market risks' in luck egalitarian theories. For example, Elizabeth Anderson expresses her concern for the increased exposure to market risks. While this could be assumed to be something quite similar to the risk structures in financial capitalism, Anderson's examples of this increasing exposure are 'declining[...] pension plans, tightening of bankruptcy laws' and more generally 'cut back of welfare state benefits' (Anderson 2007, 240). The resulting normative conclusion is that markets ought to be allowed to distribute risks, while the government ought to focus on acceptable variations of the distribution; and it is the task of theory of justice to find an optimal balance between market freedoms and a reasonable minimum standard for risk mitigation. 'We must allow the market signals to do their work', Anderson argues, (ibid., 261), yet calling for 'rangeconstraining rules'. Thus, risks are seen in as objective unforeseeabilities in 
life, merely reorganised rather than created by the market.

While these ideas can indeed be useful in determining a baseline of social protection, limitations for the analysis of financial capitalism are apparent. It is one thing to theorise mitigation of objectively existing risks or bad luck, and another to theorise equality in a society which constructs hierarchies partially on the basis of risk (avoidance). Systemic risks such as those produced by the financial system cannot be offset by the traditional means of the governments; therefore, the problem goes deeper than what the discussions on the public scope of 'range-constraints' of market risks allow.

Risks are too often seen as mere unforeseeability in life, bad luck, or side-products at best. It is indeed difficult to find a theory conceptualising the normative implications of the production of risks as the core of economic activity, risk production organising social hierarchies, or the difference between the explicit and implicit priority orders. Again, it is quite a different matter to gain social advantage by the systematic production of risks and reorganising them, than to allocate protection against existing risks unevenly. Capability theory can be useful in analysing the security of individual functionings, while Rawlsian theory helps to understand the desired scope for explicit social insurance as a division of tasks. Yet what is really needed is a theory explaining, what kinds of mechanisms and power structures should be overturned in order to have a system in which the explicit and implicit risk distribution are sufficiently overlapping. The noteworthy distinction here is the distinction between risks as the condition of uncertainty (and its management) and risks as systematically produced vulnerabilities. While the perspective of reallocation is often recognised in theory of justice, the perspective of the outcomes of risk creation is rather absent. While normative analysis of traditional social risks remains important, in financial capitalism the latter perspective becomes considerably more important.

\section{Conclusions}

Financial capitalism as a political-economic form has a distinctive logic of value creation. It entails a new logic of risk allocation, within which social justice cannot be adequately achieved with only the just allocation money and measures designed for risk mitigation in productive capitalism. Risks are not side products of economic activity, but the very nucleus of economic activity consists of generating, planning and co-ordinating risk structures. In order to form a meaningful analysis of social justice in financial capitalism, the issue of risk structures deserves attention. 
So how would a plausible normative account look? My main point here has been that (existing elements of) financial capitalism forces a reconsideration of the ontology of risk: risks are not exclusively 'social risks', or side-effects of production, but a central category in the value creation process. There should also be more analysis on the implicit orders, that is, hierarchical structures which materialise only in an event of the realisation of a systemic risk. Generally, theory of justice should focus more on vulnerabilities, and this cannot be limited to 'social insurance'. A plausible theory of justice would also make the distinction between risks which are systemic to the extent that measures against them cannot even theoretically be taken by individuals, and risks which can (at least theoretically) be chosen to take. To address the discrepancy between the explicit and implicit logics, a baseline of the level of protection needs to be defined, which is not subject to other priorities or compromise in a time of crisis, in other words a sufficient baseline existing also in what I have called above the implicit priority order.

Naturally, there are a number of political remedies suggested for the problems caused by financial capitalism. Some of them relate to what has been discussed in this article. For example, some proposed policies would limit the size and the inter-connectedness of banks. Some would take measures against externalising risks. All in all, a comprehensive theory of political economy is naturally needed, but also a theory of justice should be constructed to inform the theory of political economy.

Using a theory of justice designed for the conditions of productive capitalism, it becomes difficult to see the struggle over risk allocation and protection as anything but reorganising protection from externalities or uncertainties of life. The danger is, that some unjustifiable hierarchies are not recognised by a normative vocabulary designed to assess social justice within a social form which is already giving way to another form. On the other hand, once the role of risks as the nucleus of value production and their distribution as a key issue in political struggle are recognised, the image changes. Money has not become unimportant, far from that, but also other social hierarchies are built into the structure of the current social order.

Teppo Eskelinen works as a university lecturer in international development at the University of Jyväskylä, Finland. He obtained his PhD in philosophy from the same university, and has also taught social and public policy. His main research interests relate to the intersections of economy and social justice, both from the perspective of global justice and new forms of capitalism. Eskelinen also functions as the chair of the Finnish Society for Political Economy Research. 


\section{Bibliography}

Anderson, Elizabeth (2007) 'How should egalitarians cope with market risks?' Theoretical Inquiries in Law, 9:1, 239-270

Brighouse, Harry \& Robeyns, Ingrid (2010) Measuring justice. Primary goods and capabilities Cambridge University Press, Cambridge.

Calhoun, Craig \& Derluguian, Georgi (eds.) (2011) Business as usual: the roots of the global financial meltdown New York University Press, New York, USA

Cherry, Christopher (1973) 'Regulative rules and constitutive rules' The philosophical quarterly 23:93, pp.301-315

Dash, Mike (1999) Tulipomania. The story of the world's most coveted flower and the extraordinary passions it aroused Gollancz, London

Denning, Steve (2013) 'How can bankers recover our trust?' Forbes, Feb 6th 2013. http://www.forbes.com/sites/stevedenning/2013/02/06/will-we-evertrust-bankers-again/\#3f6a3ef9377d

Eskelinen, Teppo \& Mäkinen, Jukka (2014) 'Financial risks and the division of moral labour' SATS Northern European journal of philosophy 15:1, pp.55-74

Fleischacker, Samuel (2005) A short history of distributive justice Harvard University Press, Cambridge, Mass.

Forbes (2015) 'The two things investors are overlooking in GM's recent earnings report' Forbes April 28, 2015.

http://www.forbes.com/sites/greatspeculations/2015/04/28/two-thingsinvestors-are-overlooking-in-gms-recent-earnings-report/\#f24d0c2778fa

Gill, Stephen (1998) 'European governance and new constitutionalism. Economic and monetary union and alternatives to neo-liberalism in Europe' New Political Economy 3:1, pp.5-26

Gurria, Angel (2011) 'Addressing the social impact of the crisis. An address to a high-level parliamentary seminar'

http://www.oecd.org/employment/addressingthesocialimpactofthecrisis.ht $\underline{\mathrm{m}}$ 
Hall, Peter A \& Soskice, David (2001) Varieties of capitalism. The institutional foundations of comparative advantage Oxford University Press, Oxford

Harcourt, Bernard E (2012) The illusion of free markets. Punishment and the myth of natural order Harvard University Press, Cambridge Mass.

Kothari, Vinod (2006) Securitization: The financial instrument of the future

Kowalski, Tadeusz \& Shachmurove, Yochanan (2011) 'A historical walk through the recent financial crises' PIER working paper 19-2011. University of Pennsylvania, Philadelphia

Kregel, Jan (2014) 'Regulating the financial system in a Minskian perspective' in Luiz Carlos Bresser-Pereira; Jan Kregel \& Leonardo Burlamaqui (eds.) Financial stability and growth. Perspectives on financial regulation and new developmentalism Routledge, Oxon

Langley, Paul (2009) The everyday life of global finance. Saving and borrowing in Anglo-America Oxford University Press, Oxford

Larner, Wendy (2006) 'Neoliberalism: Policy, ideology, governmentality' In Marieke de Goede (ed) International Political Economy and Poststructural politics Palgrave MacMillan

LiPuma, Edward \& Lee, Benjamin (2004) Financial derivatives and the globalization of risk Duke University Press, Durham \& London

Liu, Henry C K (2010) 'Financial globalization and recurring financial crises' Asia Times Online, July 29, 2010

Marazzi, Christian (2011) The violence of financial capitalism MIT Press, Cambridge Mass.

Martin, Randy (2002) Financialization of daily life Temple University Press, Philadelphia, PA.

McMurtry, John (2013) The cancer stage of capitalism Pluto Press, London

Murphy, Liam \& Nagel, Thomas (2004) The myth of ownership. Taxes and justice Oxford University Press, Oxford 
Nesvetailova, Anastasia (2007) Fragile finance. Debt, speculation and crisis in the age of global credit

Nozick, Robert (1974) Anarchy, state and utopia Basic books, New York

Orhangazi, Ö. (2008) 'Financialization and capital accumulation in the nonfinancial corporate sector: a theoretical and empirical investigation on the U.S. economy, 1973-2003,' Cambridge Journal of Economics, 32(6): pp.863-886

Orhangazi, Ö. (2014) 'Financial deregulation and the 2007-08 US financial crisis' FESSUD Working paper No 49. http://www.fessud.eu/wpcontent/uploads/2013/04/Financial-deregulation-and-the-2007-08-US-financi al-crisis-Working-Paper-49.pdf

Palan, Ronen; Murphy, Richard \& Chavagneux, Christian (2009) Tax havens: how globalisation really works Cornell University Press, Ithaca NY.

Patomäki, Heikki (2013) The great eurozone disaster Zed books, London

Reinhart, Carmen \& Rogoff, Kenneth (2008) 'Is the 2007 US subprime financial crisis so different? An international historical comparison' American Economic Review 98, no. 2: 339-344

Reinhart, Carmen \& Rogoff, Kenneth (2011) This time is different. Eight centuries of financial folly Princeton University Press, Princeton NJ.

Rawls, John (1971) A theory of justice Belknap press, Cambridge Mass.

Rethel, Lena \& Sinclair, Timothy (2012) The problem with banks Zed books, London

Rushton, Steve (2016) 'To put bankers behind bars, Spanish citizens take the $1 \%$ to court' http://www.occupy.com/article/put-bankers-behind-barsspanish-citizens-take-1-court

Searle, John (1969) Speech acts. An essay in the philosophy of language Cambridge university press, Cambridge

Sen, Amartya (1993) 'Capability and well-being' In Amartya Sen \& Martha Nussbaum (eds) The quality of life Clarendon press, Oxford 
Sen, Amartya (1995) Inequality re-examined Harvard University Press, Cambridge, Mass.

Sherman, Michael (2009) 'A short history of financial deregulation in the United States' Center for economic and policy research, Washington DC. http://www.openthegovernment.org/sites/default/files/otg/dereg-timeline2009-07.pdf

Starke, Peter (2006) 'The politics of welfare state retrenchment: A literature review' Social policy $\mathcal{E}$ administration 40(1): 104-120

Stockhammer, Engelbert (2004) Financialization and the Slowdown of Accumulation. Cambridge Journal of Economics 28 (5), pp.719-741

Palley, Thomas I (2013) From Financial Crisis to Stagnation. The destruction of shared prosperity and the role of economics Cambridge University Press, Cambridge

Psathas, George (2005) 'The ideal type in Weber and Schultz' in Martin Endress, George Psathas \& Hisashi Nasu (eds.) Explorations of the Life-World Springer, Dordrecht

Toporowski Jan (2010) Why the world economy needs a financial crash and other critical essays on finance and financial economics Anthem Press, London

Varoufakis, Yanis (2013) The global minotaur. America, the true origins of the financial crisis and the future of the world economy 2nd edition. Zed books, London

Vicarelli, Fausto (1984) Keynes. The instability of capitalism Palgrave MacMillan, London

Watson, Matthew (2007) The political economy of international capital mobility Palgrave MacMillan, London

Wolff, Jonathan \& DeShalit, Avner (2007) Disadvantage Oxford University press, Oxford

World Bank (2016) 'Financial sector' World bank databank. http://data.worldbank.org/topic/financial-sector. Retrieved 22. Nov. 2016 


\section{Endnotes}

1 A deep sense of injustice is of course impossible to theorise comprehensively, but for a few popular and official reflections, see Gurria 2011; Rushton 2016; Denning 2013.

${ }^{2}$ On the 'currency of justice', see Sen 1995, chapter 1; Brighouse \& Robeyns 2010.

${ }^{3}$ On varieties of capitalism, see for example Hall \& Soskice 2001, pp.8-9

${ }^{4}$ It needs to be remembered ideal-types are open to criticism related to the choice of the distinctive features: quite like with capitalism in general, one can always dispute a description of what constitutes the 'hard core' of financial capitalism.

${ }^{5}$ See for example World Bank data on credit to private sector as GDP share in World Bank 2016

${ }^{6}$ Either the market is seen as spontaneous, with distributive measures needed 'after' the market outcome. Alternatively, the idea of spontaneous market can be refuted as the functioning of the market itself is based on politically designed institutions (Murphy \& Nagel 2004; Harcourt 2012).

${ }^{7}$ For following the relations between the car producer and its financial arm, see Forbes 2015.

${ }^{8}$ The situation of banks being 'too connected to fail' leads to a situation in which bail-outs in an event of a crash are de facto secured. Quite often this situation is somewhat erroneously called the 'too big to fail' problem; yet the key problem is not the size of individual banks, but the deep interconnectedness of their risk structures, which means that in a crisis, a chain reaction would follow without a bail-out.

${ }^{9}$ Financial crises, causing severe compromising of 'normal' functioning of the financial markets and the social welfare systems, have become frequent. For example, the data gathered by Reinhart \& Rogoff (2008) documents the banking crises after the second world war. Financial crises begin to appear slowly in the course of the 1970s after decades of absence, increasing sharply in frequency in the late 1980s. Since the 1980's, financial crises have become a recurring cyclical phenomenon, after decades of non-occurrence. The most 
recent crises have been the eurocrisis, the US financial crash, the IT bubble, and the East Asian financial crisis (Patomäki 2013; Liu 2010; Kowalski \& Shachmurove 2011). 